\title{
A narrative of cultural occupational performance
}

\author{
Nick Pollard
}

Sheffield Hallam University, South Yorkshire, United Kingdom.

\begin{abstract}
This article considers the occupational performance of cultural participation, specifically that of the author's personal experience of being a "worker writer" and grassroots activist in the Federation of Worker Writers and Community Publishers (FWWCP). The FWWCP was a UK based organisation made up of co-operative publishers, history, literacy and writing workshops which produced narratives and other forms of writing about ordinary people's experiences of everyday life in contemporary Britain. The author relates these experiences to occupational therapy's concern with the meaning of occupation, and uses heuristic methods to reflect on the connections between this form of community activism through cultural activity and occupational concepts. The paper explores issues of the representation of social class and political consciousness which have not been visible in the professional discourse on occupation. It concludes that there is a strong case for the exploration of autobiographical and community writing in developing understanding of the cultural basis of occupation.
\end{abstract}

Keywords: Culture, Occupation, Writing, Publishing.

\section{Uma narrativa de performance ocupacional cultural}

Resumo: Este artigo discute a performance ocupacional de participação cultural, especificamente a partir da experiência pessoal do autor em ser um "escritor trabalhador" e ativista de base na Federação de Trabalhadores Escritores e Editores Comunitários (FWWCP). AFWWCP era uma organização sediada no Reino Unido que realizava edições cooperativos, histórias, alfabetização e oficinas de escrita, que produziram narrativas e outras formas de escrita sobre experiências da vida cotidiana na Grã-Bretanha contemporânea. O autor relaciona essas experiências com a preocupação da terapia ocupacional sobre o significado da ocupação e utiliza métodos heurísticos para refletir sobre as conexões entre essa forma de ativismo comunitário, através da atividade cultural, e os conceitos de ocupação. O artigo explora as questões da representação de classe social e de consciência política que não têm sido visíveis no discurso profissional em ocupação e conclui que existe um forte argumento para a exploração de escrita autobiográfica e escrita em comunidade no desenvolvimento da compreensão sobre a base cultural da ocupação.

Palavras-chave: Cultura, Ocupação, Escrita, Publicação.

Corresponding author: Nick Pollard Senior Lecturer, Occupational Therapy, Robert Winston Building Sheffield Hallam University, 11-19 Broomhall Road, Sheffield S10 2BP, United Kingdom, e-mail: N.Pollard@shu.ac.uk

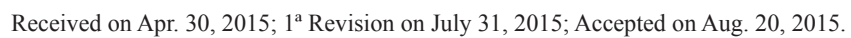




\section{Introduction}

Occupational therapists and occupational scientists have written a great deal about the occupational performance of everyday activities, such as baking (BREINES, 2005), making tea (FAIR; BARNITT, 1999), and much about life narratives (e.g. CLARK, 1993; GOULD; DESOUZA; REBEIRO-GRUHL, 2005), but less about understanding these activities as reflections of culture. Culture is insufficiently acknowledged as an underpinning of the diverse means of being and doing which are the concerns of our profession (WATSON, 2006; IWAMA, 2007). Yet occupational therapy approaches frequently involve the exchange of narratives, whether as a key element of the engagement with the client (IWAMA, 2006) as part of interventions which enable clients to achieve spiritual or enriched life objectives (ALGADO; CARDONA, 2005; WILDING; WHITEFORD, 2009), or as a component of the interaction between workers (DETWEILER; PEYTON, 1999).

Some occupational therapists are themselves involved in life history work, for example in the interviewing of retired members for the British College of Occupational Therapists (WILCOCK, 2002). Ikiugu and Pollard (2015) considered the life trajectories of worker writers as a source for exploring the concept of meaningfulness in occupation. This understanding of personal meaning is essential to a concept of occupational performance, as the conception one develops about oneself as a result of one's interactions with the physical and psychological environment over a period of time (IKIUGU, 2007, 2012). However as several Latin American occupational therapists have recently commented, cultural action is essential to the development of political and social transformations through which rights to meaningful occupation are recognised through community engagements (BARROS et al., 2011; DORNELES, 2014; GUAJARDO, 2014), and specifically through media access (CHAURA; ZORZOLI, 2014). These community engagements none the less are intimately connected to personal experiences, and narratives of this occupational dimension can be irreducible, raw, and specific, as some writers with disabilities illustrate in a new anthology (BLOCK et al., 2015a). As a therapeutic and clinical practice occupational therapy is often concerned with biomedically ordained practices and outcomes, but the personal significance of these issues belongs to a "discomfort zone" (BLOCK et al., 2015b, p. 7) inhabited by people who live with differences, exclusions and marginalisations, sometimes multiple. These barriers are not somewhere else, but operate in the communities we share. When occupational therapists regard themselves as facilitators and enablers, the narratives of the people with whom they are working might often be recounted as stories of struggle, but to appreciate this the narrative itself needs to be facilitated and a dialogue created.

So far, there has been little discussion of this type in the literature of occupational therapy despite the growing interest in social perspectives, concepts of inclusion and concerns about exclusion. This are issues of struggle, of a cultural battle around having the right to depict human occupations and activities. As professionals, occupational therapists assert their rights to classify occupation, but this has largely been without a dialogue with those who, they in effect occupy, or arguably, colonise through their practice (BLOCK et al., 2015b).

A possible antecedent for this kind of community based practice might be found in the Federation of Worker Writers and Community Publishers (FWWCP), which was a network of groups which, between 1976-2007, set out to describe the experiences of ordinary people in the diverse communities around Britain. They wrote about their occupations and their significance, producing thousands of local publications containing the narratives, life histories and autobiographies. This field of writing is one in which I have been immersed for over 30 years, and is also one in which I have previously engaged in research and theoretical discussion (PARKS; POLLARD, 2009, 2010; POLLARD, 2004, 2007; POLLARD; SMART; VOICES TALK AND HANDS WRITE GROUP, 2005; POLLARD; VOICES TALK AND HANDS WRITE GROUP, 2008; POLLARD; SAKELLARIOU, 2014). I have also attempted to relate it to occupational therapy and occupational science, where the cultural experiences from worker writing and community publishing formed part of the personal and reflective reasoning that contributed to concepts of occupational apartheid (KRONENBERG; POLLARD, 2005; POLLARD; SAKELLARIOU; KRONENBERG, 2008a, 2008b) and occupational literacy (POLLARD, 2008) as well as the discussion of life meaning (IKIUGU et al., 2012; IKIUGU; POLLARD, 2015). My collection of publications from FWWCP and similar groups, along with the FWWCP's own archive has been donated to the Trade Union Congress Library at the London Metropolitan University and further studies are to be developed from it.

This paper is developed from personal reflections prepared as positioning groundwork in the course of writing Meaningful living through occupation (IKIUGU; POLLARD, 2015), which drew some on 
the materials in the FWWCP collection to explore the ways in which ordinary people drew meaning from their life experiences. In the following account I will explore such experiences (doing, being, belonging and becoming) in relation to my participation in the FWWCP movement in the UK and my occupational performance as a "worker writer".

I used a method of heuristic inquiry to give authenticity to my exploration of the personal trajectory and participatory aspect of my experience of worker writing and community publishing (HILES, 2002; MOUSTAKAS, 1990). The heuristic process is defined itself as "a disciplined pursuit of essential meanings connected with everyday experiences" (DOUGLASS; MOUSTAKAS, 1985, p. 39), which connects with the understanding of occupational performance developed in this paper. Heuristic enquiry methods embrace tacit knowing in the process of discovery (DOUGLASS; MOUSTAKAS, 1985). Etherington (2004) describes how heuristic methods allow researchers to engage in a reflexive process that enables the personal impact of material to be considered alongside its intellectual impact. One of the underpinnings of the worker writer movement exemplified by the FWWCP is the work of Freire (1972) (MORLEY; WORPOLE, 2009), which uses discussion of the everyday as a basis for a critical consciousness linked to social origins. The consequence of all these factors suggests a strong sense of subjectivity, even intimacy (DOUGLASS; MOUSTAKAS, 1985), and therefore it seems logical to proceed from within "the experience of meaning" (POLKINGHORNE, 1982, p. 48).

Although this inquiry was referred to the chair of the ethics committee at Sheffield Hallam University it was felt that there would be no significant issues from pursuing it.

\section{Community publishing, writing and autobiography as popular occupations}

Writing has been a popular arts activity in the UK with a reasonably significant part of the adult population admitting to doing it, but the extent of participation in amateur or grassroots arts is little explored (RAMSDEN et al., 2011). Throsby (2008), reviewing the elements of creative culture in Australia, found that $75 \%$ of respondents to a census reported engagement in some form of artistic participation, and after photography $(55 \%)$ and music (37\%), 19\% reported writing fiction and $16 \%$ reported writing poetry. The most recent national survey in the UK, by Matarasso (1997), found that because it requires only a pen and some paper writing is very portable, cheap and relatively available to many people compared to occupations like photography or oil painting which may need expensive equipment.

Worker writing, or working class writing, which was the FWWCP's particular area of interest, is evident in many cultures. Similar movements exist in other European countries and have done so in other periods, notably the period between the wars in France (RAGON, 1986) and Germany (as can be seen in the Fritz Huser Institut in Dortmund www.fhi. dortmund.de/) as well as in the UK, Australia and in North America. However, amateur or grassroots forms of culture are widely disregarded (RAMSDEN et al., 2011) and the cultural experiences of working people are often silenced in the academic and professional environment (BEAGAN, 2007; PARKS; POLLARD, 2010). A review of the arts economy in São Paulo (FUNDAÇÃO..., 2011) concentrated on professional artists and enterprises, but gave some attention to the need to engage more people, especially the young and economically deprived, in a range of arts activities and related occupations. Dorneles (2014) argues for occupational therapy education to engage with community based cultural organisations and forms of expression which involve people with disabilities. There is a growing recognition that arts participation may be a key component of a civil society and in the construction of community (FUNDAÇÃO..., 2011; RAMSDEN et al., 2011).

Participation in the arts may be regarded as a form of occupational performance, and as a goal to which occupational therapists might involve their clients, since it is widely understood that arts can be linked to positive health outcomes (RAMSDEN et al., 2011). As an activist in the grassroots field of community publishing, i.e. acts of publication which are produced within communities and are usually intended to serve them, I would describe my own occupational performances, embedded in real life (CLARK, 1993), as those of a 'worker writer'.

In its application by the Federation of Worker Writers and Community Publishers (FWWCP), the term "worker writer" was used to define forms of writing that stood outside of a mainstream culture in the media and arts and came to represent the expression of a range of marginalised groups. They were not only defined by class, but also race, culture, gender, access to literacy, disability and clinical diagnosis (FROST et al., 1985; RICHARDSON, 1996; COURTMAN, 2000, 2007; POLLARD; SMART; VOICES TALK AND HANDS WRITE 
GROUP, 2005; POLLARD; VOICES TALK AND HANDS WRITE GROUP, 2008; SMART, 2005; WOODIN, 2005a, 2005b; HAMILTON; NUGENT; POLLARD, 2014). The experiences of marginalisation and standing outside the process of mainstream cultural production can be considered in terms of adaptive instrumentalist forms of behaviour with a complex and dynamic system (IKIUGU, 2007). This behaviour is directed toward the creation and operationalisation of opportunities for the expression of self and community identities. The FWWCP had formed in 1976 from a number of oral history, alternative community press, literacy and writing groups. It established a yearly weekend event at which it held its annual general meeting, workshops about writing and history and many opportunities for people to share their work through reading and performance.

Worker writing has largely been overlooked by cultural commentators. Much of what was produced by worker writers took the form of personal poems of experience rather than prose autobiography. Of course, few writers actually earn enough to sustain themselves entirely through writing (THROSBY, 2008), but people who write professionally generally establish a regular routine for writing. Because worker writing takes place within the demands of working and domestic life it mostly favours brief forms such as the short story or poem. Many write in tea breaks, on the bus, on the back of time sheets, or on the kitchen table. Frequently this kind of writing is not intensely worked over and tends to be immediate in purpose, for example, intended for performance rather than quiet reading. At the annual FWWCP meetings people would stand before the mike and read pieces that were the first they had learned to write, or recite work they had composed orally (MORLEY; WORPOLE, 2009). Live reading or recitation was a means through which a successful occupational performance as a "worker writer" was recognised.

Some writing was also informed by oral history processes which were concerned with popular experiences (MORLEY; WORPOLE; POLLARD, 2009; WORPOLE, 1981; YEO, 1981, 1986). However, there is a genre of "working class" autobiography within the writing produced over the 30 years of the FWWCP's existence, a tradition which has its roots in the earlier history of the growth of literacy in the industrial and post-industrial era (VINCENT, 1981; MORLEY; WORPOLE, 2009; WORPOLE, 1983). People have documented their life narratives which are in effect assessments of their own occupational performance. Often these narratives were written as a record of the personal impact of social and cultural change intended for the authors' children and grandchildren (VINCENT, 1981).

At the end of the last century the development of cheaper and more accessible print technology through offset litho presses and home computers made the process of writing and publishing books much easier. Community based printshops made it possible for everyone to become their own typesetter (MORLEY; WORPOLE; POLLARD, 2009). Books could be distributed quite intensively within a small locale, such as a particular community within a town. While the sale of a thousand copies of one book may not seem significant on a national scale, it could represent a high readership within one town (WORPOLE, 1983).

\section{Becoming and being a "worker writer"}

From a strictly Marxist perspective my adoption of the "worker writer" position might be quite tenuous, as will be explored, but then Marx was never a true member of the proletariat; he was an academic. While these issues may represent the initial cultural conditions for some aspects of my later development of a political exploration of occupational therapy, they also describe some of the wider issues about what Ikiugu calls (IKIUGU, 2007, p. 126) "self organisation" and "emergence", and also "perturbations" and "adaptations" which arise from the challenges encountered by complex, dynamic systems. These systems (in this instance implying both individuals and organisations) operate in a set of conditions in which various pressures 'attract' elements of the trajectory (through a "basin of attractors") they take towards outcomes (IKIUGU, 2007 , p. 126). What follows then is not only about my occupational performance as a worker writer, but also the occupational performance characteristics of the organisation in which I was involved.

Gramsci $(1971,1985)$ discussed the importance of knowledge which is derived from practical experience and comes from the bottom up. Yet this knowledge is not given as much significance as that which is derived from other sources, such as academic material. In the process of translation into organised knowledge the act of writing is itself a part of the process of knowing and understanding, as much derived from the creative engagement in the use of metaphor and the exploration of personal meanings as in the isolation and objectification of phenomena for the critical gaze (RICHARDSON, 1998). 
Furthermore in the process of my own occupation in the field of writing and community publishing both the writing process and the engagement with its discussion and actions around it through different workshops has produced "a continual cocreation of self” (RICHARDSON, 1998, p. 349). As a result of the dynamic interaction with others I have experienced, read and reflected on a diversity of occupational engagements and their exploration through literatures to which I might not otherwise have been exposed.

It is therefore important to establish the initial conditions of the trajectory of becoming a 'worker writer' to which the occupational performance of writing might be sensitive. I began writing as a schoolboy. This desire to write was stimulated by my father who was a journalist and later wrote many factual books for children. However, creative writing lessons at school, when I was nine, also seem particularly significant. Our teachers took us into the boiler room, or around the field in the wind, or to watch a mechanical digger and then encouraged the writing of poems based on our impressions. I continued to do this at home with no intention of becoming "a poet", though I too entertained an ambition to become a journalist. However I only just passed my first degree and for the next decade would experience a series of part time, temporary or low paid jobs, periods of unemployment. Further courses in journalism and teaching did not materialise in career changes.

Shortly after graduating in 1979 I joined a local writers' workshop, called Heeley Writers (Heeley is a part of Sheffield). I hoped that developing my writing skills would somehow be useful in pursuing journalism, and had begun writing short stories. The workshop was run on very democratic lines. Anyone could convene it; all members' opinions on the writing were equally valid (though some people were persuaded to leave if they wrote material that was deemed sexist or racist). The workshop gave and received supportive feedback to writers of all sorts, young and old, men and women, white and black, and at various stages of their craft. This created a set of conditions whereby members' experience of writing could, in occupational performance terms, be regarded as "self similar" (IKIUGU, 2007, p. 125). However, while some members regarded writing was a social diversion affording a night out every week, others were writing more seriously. Several published their work in commercially produced books and magazines, a couple became full time writers.

At this time I mostly wrote short science fiction stories, modelled on some of the socially concerned writing of Frederic Pohl and Cyril Kornbluth, and Philip K Dick. I felt that the fundamental science fiction question, "what if?" should be applied to immediate social circumstances with regard to time (in the early 1980s) and place rather than situated in a far away future. This was the period of what might now be regarded as the Thatcher revolution in Britain, the beginning of neoliberalism. My stories were mostly set in an imaginary decayed housing estate, "The Slumps". In The Slumps everyone was either on social security benefits or a wage that was little better, the consequence of increasing disparity between the rich and a mass of the poor. The characters had adapted to a life of low expectation. One of these stories, "Fred", (POLLARD, 1983) was eventually published in a Hackney Writers' collection when I moved to London (Hackney is an area in East London).

In Fred a couple use a robotic childminder to look after their son in order to maintain their meagre income. Fred, the robot, is built from spare parts stolen from the factory where the father works, but it is simple, and outwitted by the child, who manages to over-ride an automatic cut-out button on its battery charger, and destroys it. However, he finds in doing so he has lost an important relationship with a social companion. Science fiction was not really seen as an orthodox approach to "worker writing" by some of the group members, but I felt that I was attempting a kind of social realist approach to it, a writing grounded in contemporary reality. This defence was accepted sufficiently by the rest of the workshop for the story to be published in its anthology.

The book was perfect bound, a "proper" paperback compared to the pamphlets in which other writing had appeared, and it was sold up and down the country in radical bookshops rather than merely to friends. Thus it seemed to be a "real" publication, which also allowed me to be represented in the communities which I inhabited, as a Hackney Writer. Hackney Writers was a similar group to that at Heeley but much more mixed in age range and ethnicity. Hackney Writers was part of the FWWCP and based at Centerprise, a radical bookshop and publisher, café and meeting place.

Through attending these workshops and reading more locally produced books I felt that what we were doing as worker writers was much more than just literature, that we were exploring the groundwork for social change, a way of seeing the fabric of society differently through unheard voices. Several community published books brought this home to me. The first was Working Lives (1979). 
As I opened this in the bookshop I recognised the Greek Cypriot who often sold me fish and chips (CHRISTOU, 1979). His chapter described how he had come to work and set up a business in the UK. Other chapters were written by local community members, taxi drivers and hair dressers. This was so immediate that I bought it. Similarly, The Republic of Letters (MORLEY; WORPOLE, 2009), first published in 1982, described the diversity of the whole worker writing and community publishing movement. Many contributions were from people in the workshop I was attending. I used this as a catalogue from which to identify similar reading.

In 1983 I returned to Sheffield, where I became unemployed. In 1984, the first time I attended the FWWCP festival, I acquired William Muckle's (1981) No Regrets. At the time of the 1926 general strike Muckle had taken part in the derailing of the "Flying Scotsman", a prestige express train from London to Edinburgh, driven by strike breakers. This was not the history I had learned in school, but, as Krantz (1988, p. 8) termed it, "history from below", a self aware popular or people's history (CENTERPRISE, 1979; WORPOLE, 1981) based in the ideological resources of ordinary people (RUDE, 1980).

Within the FWWCP there was a considerable resistance to some external values, for example of literariness or correct English, in preference to vernacular language and the voice of working experience (MORLEY; WORPOLE, 2009; WOODIN, 2005a, 2005b).

The FWWCP did not take a narrow view that all writing had to reflect a working class consciousness and was not based in any political group. It was an independent radical movement. It was also at odds with the patriarchal cultural perspectives of the moderate left (MORLEY; WORPOLE, 2009). As Jo Stanley (1997) has remarked, the FWWCP view of class was more celebratory than ideologically blinkered.

This contrasted sharply with the views of people I knew from the various UK far left parties. I found that there little accommodation between the political priorities they expressed and the spontaneous and creative consciousness raising activities FWWCP members enjoyed. That the great number of such people should be "marginal" to a culture defined by a smaller but dominant population is itself paradoxical. Worker writer has therefore not been a term applied to a narrowly defined group, at least, not by FWWCP members, who opened up to many marginalised groups (e.g. COURTMAN, 2000). (As the organisation rebuilt itself in 2008 following a loss of funding, it dropped the "worker" prefix, but retained a similar inclusive ethos). Over the years I came to recognise the value of having this diverse and complex base for cultural activism without the limitations and oversimplifications of party doctrine towards which at times I veered.

Such encounters with other organisations seemed to affirm the value in being organised from the "grass roots" in a continuous poetry of everyday life through activism (VANEIGEM, 1983) rather than through a union or party hegemony. This does not necessarily entail a rigidly "bottom up" perspective, but at least requires an open or diverse peripherality or 'other space' of the kind perhaps described by Lefebvre (1991) and Soja (1989, 1996). I have experienced this space as one for what both Soja (1996) and Wilcock (1998) have termed being and becoming, through a process by which both groups and individuals have asserted their belonging from the margins. I am not suggesting that the writing from FWWCP members constitutes or intends to offer a major philosophical discourse. Instead it often reflects a quiet challenge to the dominant excluding perspectives by setting forth the part of ordinary people in the geographical, historical and social community spaces of our present society (MORLEY; WORPOLE; POLLARD, 2009), perhaps as a decolonising practice acting against the dominant discourses (BLOCK et al., 2015b).

I began collecting community publications and became active in the FWWCP myself, getting elected to the executive committee and eventually editing the organisation's magazine, Federation. As the FWWCP developed its international profile I also went with other members to conferences and other meetings with similar groups, some of them FWWCP members themselves, in Ireland, France, Germany and the USA.

Like many FWWCP writers, I became more interested in poetry than prose. Although a poem can be of any length, the construction of lines and verses facilitates the development of a piece of writing while being engaged in other occupations. The writing can be broken into small sections, each of which can be developed as an element within a linked unit in larger poem. Most poetry tends to be shorter and more manageable than an epic length, so the accomplishment of a satisfactory occupational performance outcome is more likely. Through the influence of other FWWCP members, particularly following a workshop/seminar on Irish and bardic poetry, I became interested in developing a critical understanding of technique. However I already spent a lot of time writing, drafting and redrafting, working out lines in my head, trying out images 
and the resonance of words, playing with structures, sometimes for weeks on end. After this it was good to be able to read the results to a workshop, or to an audience, and experience people reacting in ways that you hoped that they might. Quite often they didn't, and the piece would have to be worked over. The workshop process was a continuous conversation around the placing of words and the working out of meanings, of listening to and learning from other people, of trying things out.

My poems were often about personal issues. I felt had they to come out of conviction if they were to have any strength. Poetry writing was an important and engaging activity, and I often took steps to try and cultivate it by reading other poets, sometimes aloud, with a view to finding tools that I could use, listening to particular music to suggest a rhythmic base over which to lay some words, and going for walks to generate a kind of creative flow. Csiksentmihalyi's (1991) description of flow experience resonates with this personal approach, as does Winnicott's (1991) ideas about creativity occuring within a safe space, albeit one maintained in a section of one's consciousness. I sometimes found the exercise of writing poetry useful as a student since it gave me a free thinking space away from the tasks I had in hand with my course work, but little of my poetry has remained satisfactory to me.

\section{I, Omnibus, an abortive experiment in "working class writing"}

The piece of my writing that I suppose most conforms to the "worker writer" mould was an abortive novel firmly located in my experience of working as a bus conductor in Sheffield between 1980 and 1981; my friends referred to it as "I, omnibus". Bus conducting was one of a series of occupations I took up, like many other people working on the buses, between other jobs. In the mass unemployment of the 1980s I was unsure that I would find another or indeed any permanent job. Bus workers had a distinctive culture based in the pattern of shift work which produced a form of social isolation. Other people worked a 9-5 week in the jobs that bus workers took them to, and when they went out in the evening, they were relying on bus workers to get them home. The effects of these shift patterns disrupted the natural rhythm of personal and social life. They made it difficult to sleep and sometimes even to eat at regular hours. One of the justifications I took for writing the novel was to try and represent the kind of life that such a shift system produced.

I found this social world to be rich in incident and banter, long conversations during 8 hour shifts with various drivers, and sometimes passengers. The people I worked with came from a wide range of previous occupations, some of them using their alternate mornings or afternoons to pursue their own small businesses. I attempted to write about all this, trying to use the range of idioms and examples of the sometimes scatological nicknames my mates employed, to make the incidents amusing to a lay reader, and to build it around a plot of self-discovery.

When I tried to resurrect something from it some years later, I found the content was too distanced from the working culture I had earlier felt myself to be immersed in. While at the time of writing I had intended to be honest and truthful to my experiences, in my later reading it seemed to present social class as an object for humour. I feared there might be comparisons with a popular British television comedy of the late 1960s and 1970s called On the buses. This had established cultural stereotypes from which it would be difficult for a book about public transport workers to escape, and my former workmates might be insulted. I was a middle class individual with a Marxist polytechnic education fresh from the student cocoon; despite their left wing orientation my literary models were predominantly middle class, acquired through dominant cultural forms reproduced in classes. Even the writer workshops replicated this cultural dominance. I felt that I was just learning about the realities of capitalism that many of my work mates had already grappled with. Rather than a narrative of self-discovery, it was more of an exercise of reportage on Sheffield's vernacular culture by a southerner (I originate from Kent, in the UK's south) in a northern city; it might even have been interpreted as a colonising perspective.

These aspects of culture, representation, and social location which impinged on my capacity to perform occupationally as a "worker writer" were "disequilibriating” (IKIUGU, 2007, p. 126). Finally, James Kelman (1984) published The busconductor Hines. After this my work would appear to be a poor imitation. It went into the recycling bin.

Reflecting on this now, bus conducting was a job I had enjoyed because of my exposure to cultural difference and because of the stream of narratives it involved, and I felt a learned a great deal from it. However, the problem with the young man's novel of self-discovery is that since it is written while still in the condition of being a young man it is bound to fail in its project: at what point can it be said that 
the self has been discovered? In some ways I regret this crisis of confidence in what I'd written quite meticulously from my own experience, but think what I have learned from it is that authenticity may not be about immediacy, and may require some distillation to evoke the sense of that period of 1980s British neoliberalism.

None the less having edited a community publishing magazine, enjoyed sharing writing with other worker writers, participated in a number of different workshops and worked with workshop members in producing a range of community publications, served for many years in the FWWCP executive committee and as the chairperson of a literacy co-operative, participating in and representing the organisation at a range of events in the UK and abroad and having written elsewhere about practices and theory, I can point to a good number of successful occupational performance outcomes which enable me to recognise myself as a worker writer and community publisher.

Yet, as I became involved in education and writing academic texts, I have had far less time available to play around with words and form, which I regret. These exploratory and creative spaces may seem a luxury in the busy working lives of many people, but they have been part of my occupational engagement in life for over a quarter of a century. At present I am involved in a number of academic and research writing projects, but if I had a workshop audience with which to exchange and share the development of poetry could happily return to it.

\section{Writing in the broader occupational context}

This experience of engagement in working class writing and community publishing as a mode for representing various kinds of meaning has been one of "emergence" (IKIUGU, 2007, p. 126) through presenting an alternative, even a separate form of literature. But the separation has by no means been clear. None of these writing and publishing occupations really came out of a hermetically defined class environment, nor could it have happened if there was not interplay between the class elements of culture. As Worpole (1983) points out, there are many reading publics and in the sponsorship and patronage of writing there have often been different forms of encouragement which also exert influence, both positive and negative. Much of the writing I have read and listened to, as well as my own, has been pursuing currents in the sea of genres, and of attempting the use of genres as critical tools for consciousness raising, as I tried with science fiction. Furthermore, with regard to the occupational performance of my own writing, there have to be critical and pragmatic questions of "is this worth saying?", and "how 'good' can I make this?" which in turn depend being able to test one's work with an audience to establish what kind of response it gets. Therefore there is no point in writing unless there is an intention to publish. Publication for its own sake is no use unless there is an audience. For an audience to read or hear what one has written there has to be something that it can connect with, which relates to its own experiences and perceptions.

With fellow FWWCP members writing was a continuous process, we talked at length about our writing and shaped our material in workshops. I keenly anticipated reading the books which I knew were coming out. Many of these authors were and remain personal friends in a community of people who wrote. This powerful experience has informed my understanding of politics as having a strong personal element, and the importance of the representation of the self, a personal enactment of citizenship through expression, and thus through occupation. Therefore I have pursued the dialogical connection between occupation based intervention and the political (POLLARD; SMART; VOICES TALK AND HANDS WRITE GROUP, 2005; POLLARD; SAKELLARIOU; KRONENBERG, 2008a, 2008b; POLLARD, 2007, 2008). Frank (2004, p. 209) has described this kind of process as "thinking with stories", and this appears to resonate with the kind of experience that involvement with the FWWCP gave.

The topic of many of these writings and performances was the significance of everyday experience, an exploration of the extraordinariness of the ordinariness of the many little things that De Certeau (1988) recognises as underpinning a shared social fabric. When in 1988 I began training as an occupational therapist I was surprised to find that despite the discussion of the taking of occupational histories and even of narratives and the occupational concern with what people did, the outcome of intervention was often limited by the medical priorities of treatment. When I investigated the ways in which the profession viewed writing and the development of narratives in practice for my occupational therapy studies, I found that discussion was limited to the use of writing as a therapeutic medium, concerns with the physical capacity for handwriting, but there was at that time little evidence of the application of writing as a critical cultural tool in the way my FWWCP colleagues considered it (POLLARD, 
2004). It was certainly not regarded as a form of social activism.

Shortly after I qualified as a therapist in 1991 a national network called Survivors' Poetry joined the FWWCP. These writers performed work about their situation as people who had been diagnosed with mental illness conditions. They questioned the dominant hegemonic paradigms about psychiatry, social justice and the capacities of people with diagnoses to determine control over their own lives. A number of survivor poets became very active as fellow executive members of the FWWCP, consequently I had many critical discussions with them around occupational therapy, psychiatry and the values of the health and social care system. Some of these discussions informed my own postgraduate studies and subsequent writing, which drew on FWWCP sources as evidence of community perspectives of psychiatry or occupational experience. Some survivor poets facilitated courses for clients in the service in which I worked (RYAN; POLLARD, 2002). As a practitioner in mental health I have found that survivor poets' perspectives continue to challenge professional and occupational frameworks (e.g. POLLARD, 2004, 2010). As a person interested in human occupation and the narratives concerned with this, I have found the community publishing movement to be the source of very rich lifelong learning experiences for which I am deeply grateful.

As a worker writer and community publisher I would argue that the concept of occupational performance applies as much to the process by which a meaningful narrative has been produced as an artefact, as to the telling and to the content. Occupational performance also suggests a space in which meaning is enacted, and requires the physical occupation of place and the assertion of one's presence in it. This is evident from the stories and experiences recounted by people with disabilities as social activists and artists (BLOCK et al., 2015a). A core component of much worker writing is that the narrative stems from being a witness to personal and community experiences and their significance in historical, geographical and cultural location, and wanting to represent these from a conviction that the story should be told (RAGON, 1986; MORLEY; WORPOLE, 2009). This rich and reflective autobiographical content resonates with the conception of occupational therapy as basis for enabling or facilitating meaningful and purposeful interventions. I've consistently argued that therefore people who write should have a go at publishing by any means they find suits them, whether performance, print or on the web (e.g. PARKS; POLLARD, 2009).
Clearly there are caveats about how much the writer should expose of their vulnerabilities, for example if they are in psychosis, to a wider and potentially hostile or predatory community. It is impossible to retract what has been made public. For good clinical reasons there has to be a separation between the therapeutic value of writing which can remain in a confidential space and the value of publishing that writing. Yet the publication process can itself be a therapeutic occupation which involves both self-discovery and a shared awareness (POLLARD, 2004). With respect to my own writing I have often been dissatisfied with the result, and while I enjoyed sharing it at the time have regarded producing it as a learning experience. What survives is a document of where my writing had got to, and the reflections I had at the time on my occupational experiences.

If I return to my reflections on writing about my own experiences, it is clear that there was a crisis of confidence in my capacity to adequately represent this. This suggests a problem of recognition, perhaps even my own inability to recognise the validity of my own experience. These issues were related to the difficulty with which I negotiated the young adult stages of my life through a context of employment difficulties - an extended time of uncertainty. These were issues of authenticity that I could see reflected in the experience of others through the writing I was encountering, (e.g. MILLS, 1979) and yet could not completely affirm for my own experience because I did not until some time later have the integrity (ERIKSON, 1997) to know how to accommodate them. For example I felt through most of the 1980s that I had failed to achieve a career path which my parents would recognise as a return on their investment in me (not that I was not assured of their love, but I had a duty to meet their expectations). I could moan about it, but this crisis of occupational performance was really a narcissistic diversion from pulling myself out of it.

Writing and the process of reflection on the activities around occupational narrative has given me a means of reconciling these formative experiences with a critical approach to occupation based practice (e.g. POLLARD, 2008; POLLARD; SAKELLARIOU, 2014). Yet the connection between worker writing narratives and occupational narratives in occupational therapy has in part enabled me to sidestep another outcome of that crisis, which Worpole (1983, p. 94) describes: "[...] at the same time as many people acquire their first typewriter, they also acquire their first suitcase". Instead of leaving it behind, I've been able to embrace my worker writing background as an underpinning to occupational therapy, both with 
regard to being concerned with the authenticity of occupational meaning (IKIUGU; POLLARD, 2015) and, I hope, in the editorial ethos I have shared with colleagues in producing professional texts, some of which have included writers from the FWWCP and similar movements.

\section{Conclusion}

The use of my own experience in this study therefore reflects aspects that are probably common to those of other worker writers and community publishers, and others who may have written about everyday experiences. Everyone in the FWWCP or similar organisations will have come to the group they are part of with their own unique occupational history. Some have suggested that the experience has been a rich one of shared learning in which they have met people they would not have otherwise encountered (POLLARD, 2010). This has given rise to what one participant called an "organic" learning process, which others acknowledged took place over a long time (See SMART et al., 2011). Although they, and I, have found the experience of sharing these narratives very powerful, one of the central difficulties in representing this occupational experience has been finding the means to connect it to a dominant culture in order to make it recognisable. This is partly an issue of the validation of tacit or vernacular forms of knowledge as identified by Gramsci (1971, 1985) and De Certeau and his colleagues (DE CERTEAU; GIARD; MAYOL, 1998), partly one of recognising the locations from which they become (SOJA, 1996; WILCOCK, 1998) and partly about validating one's own experience for oneself. FWWCP approaches to community writing and publishing with its strong base in autobiographical writing were not only about sharing and affirming experience, but a process of identifying and confronting meanings to work towards better knowledge of the self and a basis for conjecturing how the occupational experiences of others may be constructed. Community publishing and writing activities offer a means accommodating and interpreting and contextualising personal experiences both as meaningful occupations and as contributions to culture.

\section{Acknowledgements}

Thanks are due to Moses Ikiugu for his suggestions and encouragement regarding the heuristic process on which this paper is partly based.

\section{References}

ALGADO, S. S.; CARDONA, C. The return of the corn men: an intervention project with a Mayan community of Guatemalan Retornos. In: KRONENBERG, F.; ALGADO, S. S.; POLLARD, N. (Ed.). Occupational therapy without borders: learning from the spirit of survivors. Oxford: Elsevier/Churchill Livingstone, 2005. p. 347-362.

BARROS, D. D. et al. Brazilian experiences in social occupational therapy. In: KRONENBERG, F; POLLARD, N.; SAKELLARIOU, D. (Ed.). Occupational therapies without borders. Edinburgh: Elsevier Science, 2011. p. 209-215.

BEAGAN, B. L. Experiences of social class: learning from occupational therapy students. Canadian Journal of Occupuational Therapy, Ottowa, v. 74, p. 125-133, 2007.

BLOCK, P. et al. (Ed.). Occupying disability: critical approaches to community, justice and decolonizing disability. New York: Springer, 2015a.

BLOCK, P. et al. Occupying disability: an introduction. In: BLOCK, P. et al. (Ed.). Occupying disability: critical approaches to community, justice and decolonizing disability. New York: Springer. 2015b. p. 3-14.

BREINES, E. Occupational therapy activities for practice and teaching. London: Whurr, 2005.

CENTERPRISE (Ed.) Working lives volume two: people's autobiography of Hackney 1945-77. Hackney: Hackney WEA, 1979.

CHAURA, L. E.; ZORZOLI, F. M. E. Television digital desafios del proceso en Argentina: comunicacion, participacion, social y derechos humanos. In: SANTOS, V.; GALLASI, A. V. Questóes contemporâneas da terapia ocupacional na América do Sul. Curitaba: CRV, 2014. p. 185-204.

CHRISTOU, M. Fish \& chip man. In: CENTERPRISE (Ed.). Working lives volume two: people's autobiography of Hackney: 1945-77. Hackney: Hackney WEA, 1979. p. 158-165.

CLARK, F. Occupation embedded in a real life: interweaving occupational science and occupational therapy. American Journal of Occupational Therapy, Bethesda, v. 47, n. 12, p. 1067-1077, 1993.

COURTMAN, S. 'Culture is ordinary': the legacy of the Scottie Road and Liverpool 8 Writers. In: MURPHY, M.; REES-JONES, D. Writing Liverpool: essays and interviews. Liverpool: Liverpool University Press, 2007. p. 194-209

COURTMAN, S. Frierian Liberation, Cultural Transaction and Writing from 'The Working class and the Spades'. London: The Society for Caribbean Studies Annual Conference Papers, 2000. p. 1-5. Available from: <https:// www.researchgate.net/publication/237266081_ Freirian_Liberation_Cultural_Transaction_and_Writ- 
ing_from_\%27The_Working_Class_and_the_ Spades\%27\%281\%29>. Access on: 29 apr. 2015.

CSIKSENTMIHALYI, M. Flow: the psychology of optimal experience. New York: Harper Collins, 1991.

DE CERTEAU, M. The practice of everyday life. Berkley: University of California, 1988.

DE CERTEAU, M.; GIARD, L.; MAYOL, P. The practice of everyday life. Living and cooking. Minneapolis: Minnesota, 1998.

DETWEILER, J.; PEYTON, C. Defining occupations: a chronotopic study of narrative genres in a health discipline's emergence. Written Communication, Thousand Oaks, v. 16, n. 4, p. 412-468, 1999.

DORNELES, P. Accesibilidade cultural, uma nova atuação dos terapeutas ocupcionais. In: SANTOS, V.; GALLASI, A. V. Questöes contemporâneas da terapia ocupacional na América do Sul. Curitaba: CRV, 2014. p. 151-158.

DOUGLASS, B. G.; MOUSTAKAS, C. Heuristic enquiry: the internal search to know. Journal for Humanistic Psychology, Thousand Oaks, v. 25, p. 39-55, 1985.

ERIKSON, E. H. The life cycle completed. New York: Norton. 1997.

ETHERINGTON, K. Heuristic research as a vehicle for personal and professional development. Counselling and Psychotherapy Research, London, v. 2, n. 4, p. 48-63, 2004.

FAIR, A.; BARNITT, R. Making a cup of tea as part of a culturally sensitive service. British Journal of Occupational Therapy, London, v. 62, n. 5, p. 199-205, 1999.

FRANK, A. W. Asking the right question about pain: narrative and phronesis. Literature and Medicine, Baltimore, v. 3, n. 23, p. 209-225, 2004.

FREIRE, P. The pedagogy of the oppressed. Harmondsworth: Penguin, 1972.

FROST, G.; HOY, C.; GLYNN, J. Opening time. A writing resource pack written by students in Basic Education. Manchester: Gatehouse, 1985.

FUNDAÇÃO DO DESENVOLVIMENTO ADMINISTRATIVO - FUNDAP. Economia criativa na cidade de São Paulo: diagnóstico e potencialidade. São Paulo, 2011. Available from: <http://novo.fundap.sp.gov.br/arquivos/PDF/Livro_Economia_Criativa_NOVO.pdf $>$. Access on: 29 apr. 2015.

GOULD, A.; DESOUZA, S.; REBEIRO-GRUHL, K. L. And then I lost that life: a shared narrative of four young men with schizophrenia. British Journal of Occupational Therapy, London, v. 68, n. 10, p. 467-473, 2005.

GRAMSCI, A. Selections from the prison notebooks, edited and translated by Quintin Hoare and Geoffrey NowellSmith. London: Lawrence and Wishart, 1971.
GRAMSCI, A. Selections from cultural writings. London: Lawrence and Wishart, 1985.

GUAJARDO, A. Una terapia ocupacional critica como posibilidad. In: SANTOS, V.; GALLASI, A. V. Questões contemporâneas da terapia ocupacional na América do Sul. Curitaba: CRV, 2014. p. 159-165.

HAMILTON, M.; NUGENT, P.; POLLARD, N. Learner voices at Pecket: past and present. Fine Print, Victoria, v. 37, n. 1, p. 15-20, 2014.

HILES, D. Narrative and heuristic approaches to transpersonal research and practice. London, 2002. Available from: <http://psy.dmu.ac.uk/drhiles/N\&Hpaper.htm>. Access on: 29 apr. 2015.

IKIUGU, M. et al. Meaning making through occupations and occupational roles: a heuristic study of workerwriter histories. British Journal of Occupational Therapy, London, v. 75, n. 6, p. 289-295, 2012.

IKIUGU, M. Measuring occupational performance: a pragmatic and dynamical systems perspective. Journal of Occupational Science, Melbourne, v. 14, n. 3, p. 123 135, 2007.

IKIUGU, M. The test-retest reliability and predictive validity of a battery of newly developed occupational performance assessments. Occupational Therapy in Mental Health, New York, v. 28, n. 1, p. 51-71, 2012.

IKIUGU, M.; POLLARD, N. Meaningful living through occupation. London: Whiting and Birch, 2015.

IWAMA, M. The Kawa model: culturally relevant occupational therapy. Edinburgh: Churchill Livingstone/ Elsevier, 2006.

IWAMA, M. Culture and occupational therapy: meeting the challenge of relevance in a global world. Occupational Therapy International, Malden, v. 14, n. 4, p. 183-187, 2007

KELMAN, J. The busconductor Hines. Edinburgh: Polygon, 1984.

KRANTZ, F. George Rude and "history from below". In: KRANTZ, F. (Ed.). History from below. Oxford: Blackwell, 1988. p. 3-9.

KRONENBERG, F; POLLARD, N. Overcoming occupational apartheid, a preliminary exploration of the political nature of occupational therapy. In: KRONENBERG, F.; ALGADO, S. S.; POLLARD, N. (Ed.). Occupational therapy without borders. Oxford: Churchill Livingstone, 2005. p. 58-86.

LEFEBVRE, H. The production of space. Oxford: Blackwell, 1991.

MATARASSO, F. Use or ornament? The social impact of participation in the arts. London: Comedia, 1997.

MILLS, R. A comprehensive education. Hackney: Centerprise, 1979. 
MORLEY, D.; WORPOLE, K. The republic of letters. Philadelphia: New Cities Community Press/Syracuse University Press, 2009.

MORLEY, D.; WORPOLE, K.; POLLARD, N. Class identity and the republics of letters. In MORLEY, D.; WORPOLE, K. The republic of letters. Philadelphia: New Cities Community Press/Syracuse University Press, 2009. p. 223-244.

MOUSTAKAS, C. Heuristic research: design, methodology and applications. London: Sage, 1990.

MUCKLE, W. No regrets. Newcastle upon Tyne: People's Publications, 1981.

PARKS, S.; POLLARD, N. Emergent strategies for an established field: the role of the worker writer groups in composition and rhetoric. College Composition and Communication, Illinois, v. 61, n. 3, p. 476-509, 2010.

PARKS, S.; POLLARD, N. The extra-curricular of composition: a dialogue on community publishing. Community Literacy Journal, Chicago, v. 3, n. 2, p. 5377, 2009.

POLKINGHORNE, D. What makes research humanistic? Journal of Humanistic Psychology, Thousand Oaks, v. 22, n. 3, p. 47-54, 1982.

POLLARD, N. Fred. In: Hackney Writers Workshop (Ed.). Where there's smoke. Hackney: Centerprise, 1983. p. 76-80.

POLLARD, N. Notes towards an approach for the Therapeutic Use of Creative Writing in Occupational Therapy. In: SAMPSON, F. (Ed.). Creative writing in health and social care. London: Jessica Kingsley, 2004. p. 189-206.

POLLARD, N. Occupational narratives, community publishing and worker writing groups: sustaining stories from the margins. Groupwork, London, v. 20, n. 1, p. 9-33, 2010.

POLLARD, N. Voices talk, hands write: sustaining community publishing with people with learning difficulties. Groupwork, London, v. 17, n. 2, p. 51-74, 2007.

POLLARD, N. When Adam delf and Eve span: occupational literacy and democracy. In: POLLARD, N.; SAKELLARIOU, D.; KRONENBERG, F. (Ed.). A political practice of occupational therapy. Edinburgh: Elsevier Science, 2008. p. 39-51.

POLLARD, N.; SAKELLARIOU, D. The occupational therapist as a political being. Cadernos de Terapia Ocupacional UFSCar, São Carlos, v. 22, n. 3, p. 643652, 2014.

POLLARD, N.; SAKELLARIOU, D.; KRONENBERG, F. A political practice of occupational therapy. In: POLLARD, N.; SAKELLARIOU, D.; KRONENBERG, F. (Ed.). A political practice of occupational thera$p y$. Edinburgh: Elsevier Science, 2008a. p. 3-20.
POLLARD, N.; SAKELLARIOU, D.; KRONENBERG, F. Political competence in occupational therapy. In: POLLARD, N.; SAKELLARIOU, D.; KRONENBERG, F. (Ed.). A political practice of occupational thera$p y$. Edinburgh: Elsevier Science, 2008b. p. 21-38.

POLLARD, N.; SMART, P.; VOICES TALK AND HANDS WRITE GROUP. Voices talk and hands write. In: KRONENBERG, F.; ALGADO, S. S.; POLLARD, N. (Ed.) Occupational therapy without borders: learning from the spirit of survivors. Edinburgh: Elsevier Churchill Livingstone, 2005. p. 287-301

POLLARD, N.; VOICES TALK AND HANDS WRITE GROUP. Voices talk, hands write. In: CREPEAU, E.; COHN. E.; BOYT SCHELL, B. (Ed). Willard and Spackman's Occupational Therapy. Philadelphia: Lipincott, Williams and Wilkins, 2008. p. 139-145

RAGON, M. Histoire de la litterature proletariene de Langue Francaise. Paris: Albin Michel, 1986.

RAMSDEN, H. et al. The role of grassroots arts activities in communities: a scoping study. Third Sector Research Centre. Birmingham: Third Sector Research Centre, 2011. (Working Paper, 68). Available from: <http:// www.birmingham.ac.uk/generic/tsrc/documents/tsrc/ working-papers/working-paper-68.pdf>. Access on: 29 apr. 2015.

RICHARDSON, L. Writing, a method of inquiry. In: DENZIN, N. K.; LINCOLN, Y. S. (Ed.). Collecting and interpreting qualitative materials. Thousand Oaks: Sage, 1998. p. 345-371.

RICHARDSON, S. (Ed.). Writing on the line: 20th century working-class women writers: an annotated list. London: Working Press, 1996.

RUDE, G. Ideology and popular protest. London: Lawrence and Wishart, 1980.

RYAN, H.; POLLARD, N. Poetry on the agenda for Scottish weekend. Adults Learning, Leicester, v. 13, n. 5, p. 10-11, 2002.

SMART, P. A beginner writer is not a beginner thinker. In: KRONENBERG, F.; ALGADO, S. S.; POLLARD, N. (Ed.). Occupational therapy without borders. Oxford: Elsevier, 2005. p. 46-53.

SMART, P. et al. Pecket learning community - where the stem of knowledge blossoms. In: KRONENBERG, F.; POlLARD, N.; SAKELLARIOU, D. (Ed.). Occupational therapies without borders. Edinburgh: Elsevier Science, 2011. p. 19-26.

SOJA, E. W. Postmodern geographies, the reassertion of space in critical social theory. London: Verso, 1989.

SOJA, E. W. Thirdspace: journeys to Los Angeles and other real-and-imagined places. Malden: Blackwell, 1996.

STANLEY, J. To celeb-rate and Not Be-Moan. In: MAHONY, P.; C ZMROCZEK, C. (Ed.). Class 
matters, 'working class' women's perspectives on social class. London: Taylor and Francis, 1997. p. 175-189.

THROSBY, D. Creative Australia: the arts and culture in Australian work and leisure. Canberra: The Academy of the Social Sciences in Australia, 2008. Available from: <http://www.assa.edu.au/publications/occasional/2008_CS1_Creative_Australia.pdf>. Access on: 29 apr. 2015.

VANEIGEM, R. The revolution of everyday life. London: Left Bank Books, 1983.

VINCENT, D. Bread, knowledge and freedom, a study of ninteenth-century working class autobiography. London: Europa Publications, 1981.

WATSON, R. M. Being before doing: the cultural identity (essence) of occupational therapy. Australian Occupational Therapy Journal, Malden, v. 53, n. 3, p. 151158, 2006.

WILCOCK, A. A. Reflections on doing, being and becoming. Canadian Journal of Occupational Therapy, Toronto, v. 65, n. 5, p. 248-256, 1998.

WILCOCK, A. A. A journey from prescription to self health. Occupation for Health. London: British Association and College of Occupational Therapy, 2002.

WILDING, C.; WHITEFORD, G. From practice to praxis: reconnecting moral vision with philosophical underpinnings. British Journal of Occupational Therapy, London, v. 72, n. 10, p. 434-441, 2009.

WINNICOTT, D. W. Playing and reality. London: Routledge, 1991.

WOODIN, T. Muddying the Waters: changes in class and identity in a working class cultural organization. Sociology, London, v. 39, n. 5, p. 1001-1018, 2005 a.

WOODIN, T. Building culture from the bottom up: the educational origins of the Federation of Worker Writers and Community Publishers. History of Education, London, v. 34, n. 4, p. 345-363, 2005 b.

WORPOLE, K. A ghostly pavement: the political implications of local working class history. In: SAMUEL, R. People's History and Socialist Theory. London: Routledge \& Kegan Paul, 1981. p. 22-32.

WORPOLE, K. Dockers and detectives. London: Verso, 1983.

YEO, S. The politics of community publications. In: SAMUEL, R. People's History and Socialist Theory. London: Routledge \& Kegan Paul, 1981. p. 42-48.

YEO, S. Whose story? An argument from within current historical practice in britain. Journal of Contemporary History, London, v. 21, n. 2, p. 295-320, 1986. 